\title{
The Cytotoxic Action of Leucocidin from Pseudomonas aeruginosa on Human Polymorphonuclear Leucocytes
}

\author{
By W. SCHARMANN,* F. JACOB AND J. PORSTENDÖRFER \\ Institut für Bakteriologie und Immunologie, Fachbereich Veterinärmedizin und \\ Strahlenzentrum, Universität Giessen, D-63 Giessen, Germany
}

(Received 6 June 1975; revised I9 September 1975)

\begin{abstract}
SUMMARY
Human polymorphonuclear leucocytes treated in vitro with leucocidin from Pseudomonas aeruginosa underwent characteristic morphological alterations as shown by phase-contrast and scanning electron microscopy. Within a few minutes of exposure to leucocidin the granulocytes became round, and protoplasmic extrusions appeared on the cell membrane, were withdrawn again and put out at another point of the cell. The final stage of the leucocidin-treated leucocyte was an enlarged, rounded vesicle with apparently intact plasma membrane. Omission of calcium ions from the diluting buffer caused certain differences in the morphologic appearance of the damaged leucocytes.
\end{abstract}

\section{INTRODUCTION}

A preceding paper (Scharmann, I976a) describes the formation and isolation from Pseudomonas aeruginosa of a cytotoxic substance designated 'leucocidin', which damaged human leucocytes of various cell types but was inactive against erythrocytes.

The present communication describes the morphologic changes in human polymorphonuclear leucocytes treated with purified leucocidin. The studies were made under phasecontrast and with the scanning electron microscope.

\section{METHODS}

Leucocidin. Leucocidin was released from $P$. aeruginosa strain 158 by autolysis of washed cells (Scharmann, I976a) and purified by ammonium sulphate precipitation ( $20 \%$ saturation) and combined gel filtration on Sephadex G-I00 superfine and Bio Gel P-I00 (Scharmann, $1976 b$ ). The purified toxin appeared as a single band in sodium dodecylsulphatepolyacrylamide gel disc electrophoresis (Scharmann, 1976b) and was devoid of lipase, lecithinase $\mathrm{C}$, protease and haemolysin. The leucocidin solution used here contained 300 MLeD (minimal leucocidic dose; Scharmann, I976a) toxin/ml PBS.

Buffer. Phosphate buffered saline $\mathrm{pH}_{7 \cdot 2}$ (PBS) was prepared according to Dulbecco \& Vogt (1954).

Preparation of polymorphonuclear leucocytes. For phase microscopy on human blood, a finger-prick sample was taken and Io $\mu \mathrm{l}$ mixed with either $5 \mu \mathrm{l}$ leucocidin solution or $5 \mu \mathrm{l}$ PBS (as control) on a glass slide. A cover glass was added and sealed with paraffin. Observations were made at room temperature. For scanning electron microscopy, round, thoroughly

* Present address: Bundesgesundheitsamt, D-I, Berlin 33, Postfach, Germany. 
cleaned cover glasses ( $5 \mathrm{~mm}$ in diameter) were stuck on specimen support grids. Human venous blood was allowed to clot on the cover glasses and was incubated at $37^{\circ} \mathrm{C}$ for $30 \mathrm{~min}$ in a moist chamber. The clot was washed off with PBS and the remaining granulocytes treated with leucocidin solution. At different intervals the cover glasses were fixed for $3 \mathrm{~h}$ in $2.5 \%(\mathrm{v} / \mathrm{v})$ glutaraldehyde in PBS at room temperature, washed in distilled, demineralized water and allowed to air-dry at $37{ }^{\circ} \mathrm{C}$. Control cells were fixed with $0.5 \%$ glutaraldehyde in PBS.

Scanning electron microscopy. The air-dried specimens were coated with gold (approximate thickness I 5 to $20 \mathrm{~nm}$ ) in a vaporizer (EPA I00, Leybold-Heraeus, Köln, Germany) and examined with a Stereoscan $\mathrm{S}_{4}$ electron microscope (Cambridge Scientific Instruments, Ltd, Cambridge) operating at $20 \mathrm{kV}$. The specimen stage was kept at an angle of 30 to $35^{\circ}$.

\section{RESULTS}

\section{Phase microscopy}

Control cells moving with their pseudopodia showed a physiological streaming of granules from the centre of the cell to the periphery. The lobulated nucleus could not readily be differentiated from the other parts of the cell (Fig. I $a$ ). The granulocytes did not change detectably during a $\mathrm{I} h$ period of observation.

The morphological alteration in granulocytes treated with leucocidin occurred in three different stages.

Stage I. After the addition of leucocidin the motility of the cells was lost and their pseudopodia were withdrawn (Fig. I $b$ ). The physiological streaming of granules was changed to Brownian movement.

Stage 2. At between 30 and $70 \mathrm{~s}$ after the addition of leucocidin (depending on concentration) one or more vesicular extrusions appeared at different points on the circumference of the cells. In some cases the pouches were withdrawn and new ones appeared at another point of the cell membrane (Fig. I $c, d$ ). The protoplasmic extrusions were partly filled with granules in Brownian motion. Several extrusions were separated from the cell in the form of small vesicles. At the same time the lobulated nucleus became very prominent. About 3 to 4 min later the cells rounded up and became slightly swollen (Fig. I $e$ ).

Stage 3. The granules, still in Brownian movement, partly disappeared, partly clustered close to the cell membrane (Fig. I $f$ ). The nuclear lobes fused and the nucleus became spherical with distinct outlines (Fig. I $f$ ). At about $30 \mathrm{~min}$ all granules were clustered and the nucleus slowly faded away. The final stage in the sequence of leucocidin toxicity to granulocytes was a rounded, greatly expanded vesicle containing a few residual granules and possessing an apparently intact membrane (Fig. I $g$ ).

When the leucocytes were exposed to leucocidin in PBS without $\mathrm{Ca}^{2+}$, certain differences in the sequence of morphological changes were observed. Upon the addition of leucocidin, cells often did not round up. The protoplasmic extrusions appeared more vermiform than vesicular and were withdrawn only during expansion. At the final stage the granules as well as the nucleus maintained their contours for hours in the spherical swollen cell. The cells were more enlarged in the absence of $\mathrm{Ca}^{2+}$ than in its presence.

When the granulocytes were treated with leucocidin diluted in a medium consisting of PBS and bovine serum albumin ( $100 \mathrm{mg} / \mathrm{ml}$ ), cells became round and their high refractility decreased. However, only small cytoplasmic pouches appeared and there was no marked swelling. 

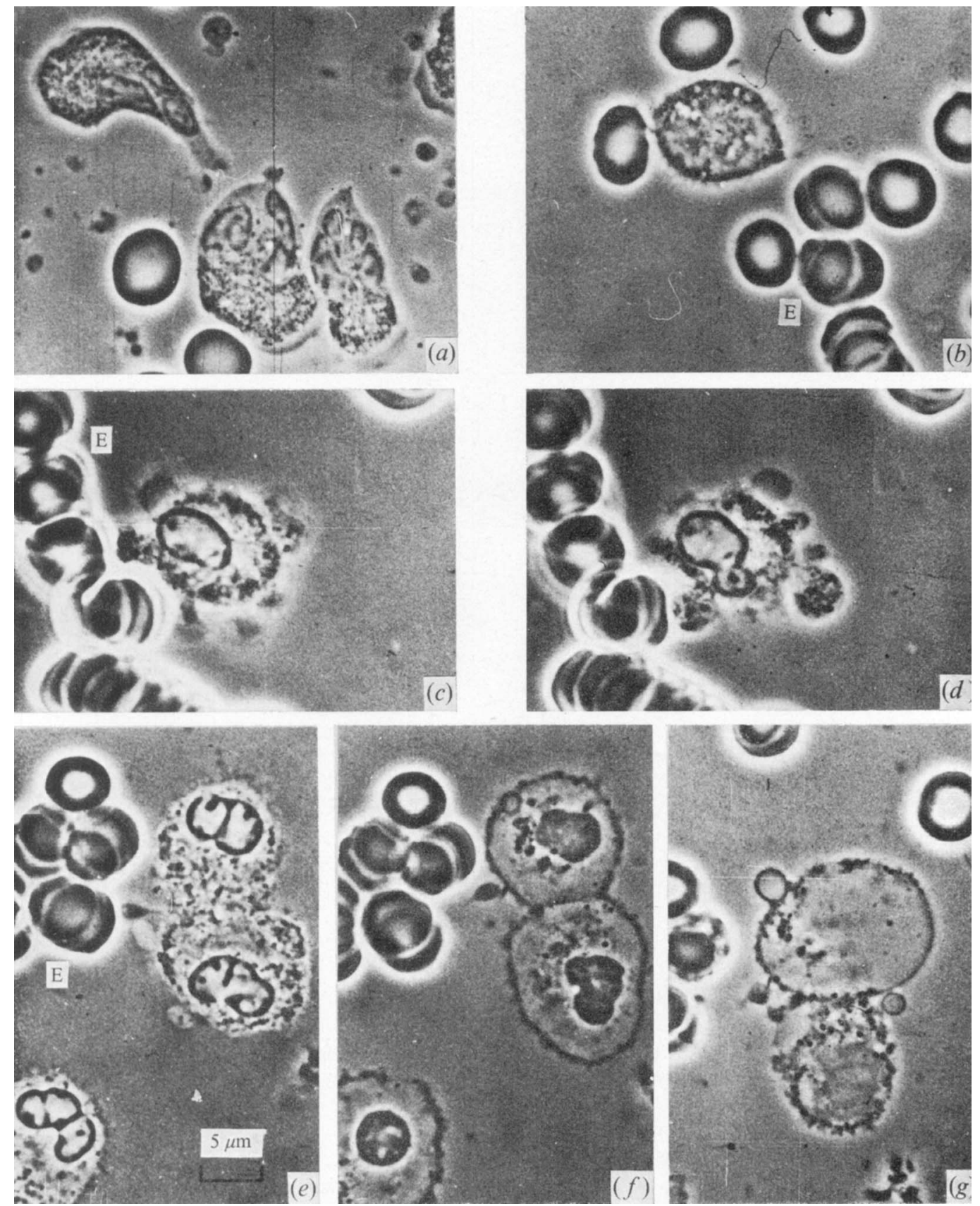

Fig. I. The effect of leucocidin on human polymorphonuclear leucocytes. Phase contrast. Control granulocytes $(a)$, granulocytes exposed to leucocidin for $20 \mathrm{~s}(b), \mathrm{I} \min (c, d), 5 \mathrm{~min}(e), 20 \mathrm{~min}$ $(f), 30 \min (g)$. E, Erythrocytes. 

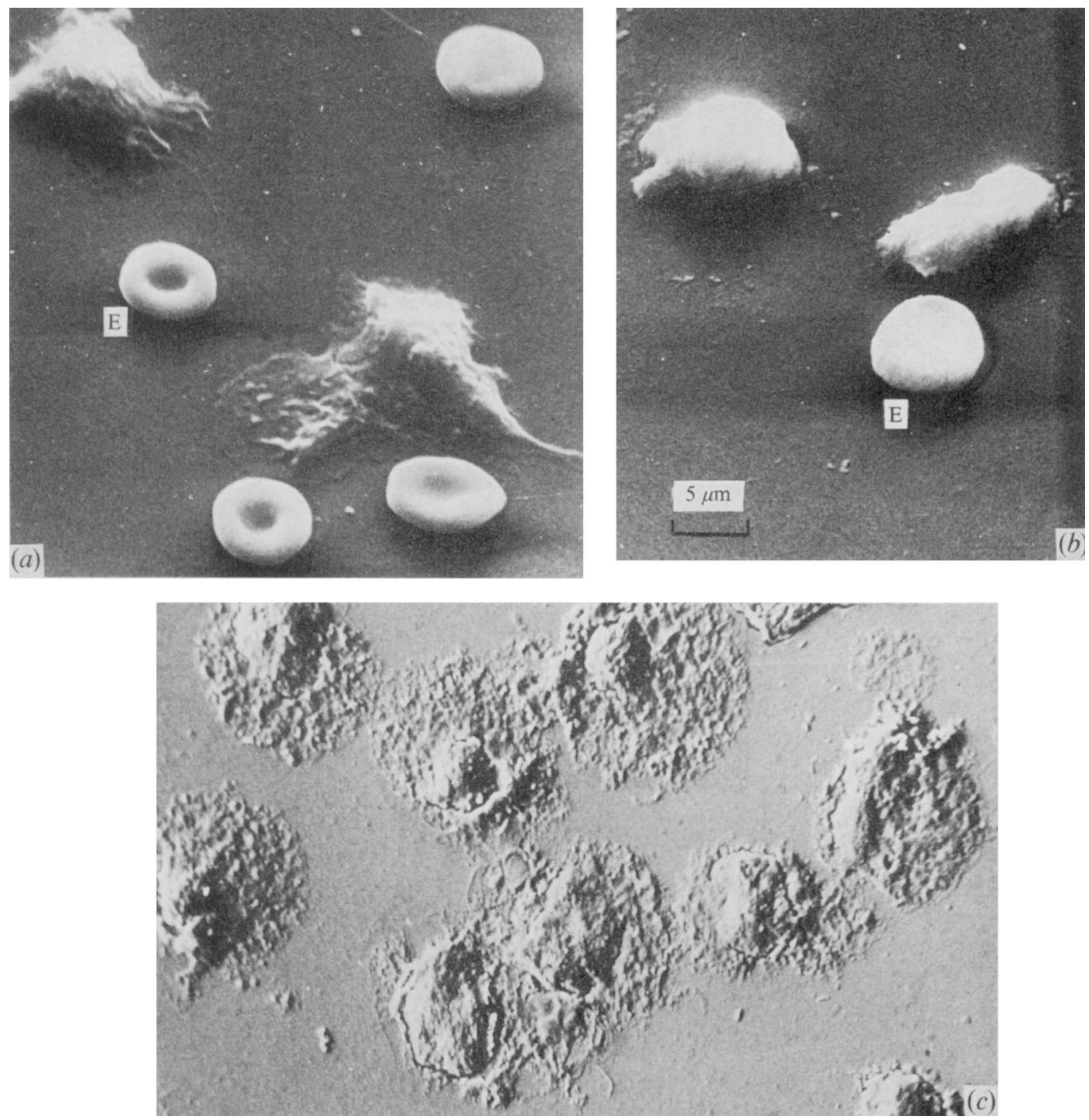

Fig. 2. The effect of leucocidin on human polymorphonuclear leucocytes. Scanning electron microscopy. Control granulocytes (a), granulocytes exposed to leucocidin for I $\min (b), 20 \mathrm{~min}(c)$. E, Erythrocytes.

\section{Scanning electron microscopy}

Examination of leucocidin-treated granulocytes by scanning electron microscopy confirmed the results obtained by phase-contrast. However, no gross alterations of the plasma membrane from poisoned leucocytes were revealed by this means. The picture of the final stage (Fig. $2 c$ ) shows collapsed ghosts, indicating that the cells had lost most, or all, of their cytoplasm. 


\section{DISCUSSION}

The morphological alterations resulting from exposure of human polymorphonuclear leucocytes to leucocidin from $P$. aeruginosa resembled the changes caused by PantonValentine leucocidin of Staphylococcus aureus (Gladstone \& van Heyningen, 1957). A similar cytotoxic effect has also been induced by anti-tumour cell antiserum and complement on Krebs ascites tumour cells (Goldberg \& Green, 1959). Both staphylococcal leucocidin and antibody with complement act primary at the plasma membrane by altering the selective permeability to $\mathrm{K}^{+}$and $\mathrm{Na}^{+}$. The earliest response of the cells following either the addition of leucocidin (Woodin, I970) or antibody with complement (Green, Barrow \& Goldberg, 1959) is a rapid loss of intracellular $\mathrm{K}^{+}$. Preliminary investigations on leucocidin of $P$. aeruginosa revealed that this toxin also induced a rapid $\mathrm{K}^{+}$and glucose loss from granulocytes within 0.5 to $2 \mathrm{~min}$ of the addition of leucocidin (Scharmann, unpublished). The $\mathrm{K}^{+}$leakage was correlated with the rounding of the granulocytes, which was the earliest visible morphological alteration.

The subsequent changes of morphology were presumably not due to the direct action of leucocidin, but may be explained by damage to the mechanism of permeability control in the plasma membrane. When the cell is unable to prevent free exchange of ions, the internal osmotic pressure rises and water enters the cell which becomes swollen. The swelling can be prevented by raising the osmolarity of the suspending medium with large molecules (e.g. albumin) which are unable to penetrate the cell membrane (Green et al., 1959). This hypothesis of 'colloid osmotic swelling' (Wilbrandt, 194I) is advanced as an explanation for a large number of cytolytic processes (Davson \& Danielli, 1938; Bernheimer, 1947; Green et al., 1959; Madoff, Cooper \& Weinstein, 1964; Woodin, 1970). With haemolytic toxins, the colloid osmotic process leads to the lysis of erythrocytes and other cells, since the haemolysins attack structurally-essential components in the membrane. Apparently this is not the case with the leucocidins and with immune haemolysis.

Calcium ions enhance the rigidity of the plasma membrane (Manery, 1969), which could explain the decreased expansion of the cell in the presence of these ions. In addition, $\mathrm{Ca}^{2+}$ is essential for membrane fusion (Poste \& Allison, 1973). Our observations show that degranulation of leucocytes exposed to leucocidin occurred only in the presence of $\mathrm{Ca}^{2+}$. In vitro experiments supported these observations, since the toxin-mediated release of granule enzymes is much higher with $\mathrm{Ca}^{2+}$ than without it (Scharmann, unpublished). This suggests that degranulation associated with exposure to leucocidin is due to the fusion of the granules with the cell membrane. The release of lysosomal enzymes from granulocytes caused by Panton-Valentine leucocidin from $S$. aureus has also been ascribed to membrane fusion (Woodin, 1970).

This investigation was supported in part by the Deutsche Forschungsgemeinschaft.

\section{REFERENCES}

Bernheimer, A. W. (I947). Comparative kinetics of hemolysis induced by bacterial and other hemolysins. Journal of General Physiology 30, 337-353.

Davson, H. \& Danielli, J. F. (I938). Studies on the permeability of erythrocytes. V. Factors in cation permeability. Biochemical Journal 32, 99I-IOOI.

Dulbecco, R. \& Vogr, M. (I954). One-step growth curve of western equine encephalomyelitis virus chicken embryo cells grown in vitro and analysis of virus yields from single cells. Journal of Experimental Medicine 99, I 83-I 99.

Gladstone, G. P. \& Van Heyningen, W. E. (1957). Staphylococcal leucocidins. British Journal of Experimental Pathology 38, 123-137. 
GoldBerg, B. \& Green, H. (1959). The cytotoxic action of immune gamma globulin and complement on Krebs ascites tumor cells. I. Ultrastructural studies. Journal of Experimental Medicine 109, 505-510.

Green, H., Barrow, P. \& GoldberG, B. (1959). Effect of antibody and complement on permeability control in ascites tumor cells and erythrocytes. Journal of Experimental Medicine r1o, 699-7I3.

Madoff, M. A., Cooper, L. Z. \& Weinstein, L. (I964). Hemolysis of rabbit erythrocytes by purified staphylococcal alpha-toxin. Journal of Bacteriology 87, 145-149.

MANery, J. F. (1969). Calcium and membranes. In Mineral Metabolism, vol. 3, pp. 405-452. New York: Academic Press.

Poste, G. \& Allison, A. C. (1973). Membrane fusion. Biochimica et biophysica acta 300, 42 I-465.

ScharmanN, W. (1976a). Formation and isolation of leucocidin from Pseudomonas aeruginosa. Journal of General Microbiology 93, 283-29I.

ScharmanN, W. (1976b). Purification and characterization of leucocidin from Pseudomonas aeruginosa. Journal of General Microbiology 93, 292-302.

WILBRANDT, W. (I94I). Osmotische Natur sogenannter nichtosmotischer Hämolysen (Kolloid-osmotische Hämolyse). Archiv für die gesamte Physiologie 245, 22-52.

Woodin, A. M. (1970). Staphylococcal leukocidin. In Microbial Toxins, vol. 3, pp. 327-355. Edited by T. C. Montie, S. Kadis and S. J. Ajl. New York: Academic Press. 